\title{
Southern African topography and erosion history: plumes or plate tectonics?
}

\author{
Andy Moore, ${ }^{1,2}$ Tom Blenkinsop ${ }^{3}$ and Fenton (Woody) Cotterill ${ }^{4}$ \\ ${ }^{1}$ African Queen Mines Ltd., Box 66, Maun Botswana $;{ }^{2}$ Department of Geology, Rhodes University, Grahamstown, South Africa; ${ }^{3}$ School of Earth \\ and Environmental Sciences, James Cook University, Townsville 4811, Qld, Australia; ${ }^{4}$ AEON - Africa Earth Observatory Network, and \\ Department of Geological Sciences, and Department of Molecular and Cell Biology, University of Cape Town, Rondebosch 7701, South Africa
}

\begin{abstract}
The physiography of southern Africa comprises a narrow coastal plain, separated from an inland plateau by a horseshoe-shaped escarpment. The interior of the inland plateau is a sedimentary basin. The drainage network of southern Africa is characterized by three river divides, broadly parallel to the coastline. These features contrast strongly with the broad dome and radial drainage patterns predicted by models which ascribe the physiography of southern Africa to uplift over a deep mantle plume. The drainage divides are interpreted as axes of epeirogenic uplift. The ages of these axes, which
\end{abstract}

young from the margin to the interior, correlate closely with major reorganizations of spreading regimes in the oceanic ridges surrounding southern Africa, suggesting an origin from stresses related to plate motion. Successive epeirogenic uplifts of southern Africa on the axes, forming the major river divides, initiated cyclic episodes of denudation, which are coeval with erosion surfaces recognized elsewhere across Africa.

Terra Nova, 21, 310-315, 2009

\section{Introduction}

In broad outline, the physiography of southern Africa is characterized by a narrow coastal plain of low relief, separated by a horseshoe-shaped escarpment from an inland plateau standing at more than $1000 \mathrm{~m}$ above sea level (Bond, 1979; Fig. 1). The elevation of this plateau is atypically high compared with the average of 400-500 m for cratons on other continents (Lithgow-Bertelloni and Silver, 1998; Gurnis et al., 2000), and forms part of a belt of high ground that extends to east Africa, constituting the 'African Superswell' (Nyblade and Robinson, 1994). Recent attempts to account for this elevated topography have generally invoked variations of the mantle plume concept (Nyblade and Robinson, 1994; Burke, 1996; Ebinger and Sleep, 1998; LithgowBertelloni and Silver, 1998; Gurnis et al., 2000). Indeed, modelled mantle density and viscosities (Gurnis et al., 2000) assume uplift in southern Africa to have been plume-related. The African erosion surface, associated so closely with Africa's anomalous

Correspondence: Dr Tom G Blenkinsop, School of Earth and Environmental Sciences, James Cook University, Townsville Campus, Townsville 4811, Qld, Australia. Tel.: 006174781 4318; fax: 00 6174725 1501; e-mail: thomas.blenkinsop@ jcu.edu.au elevation, is interpreted as a polygenetic landform (Burke and Gunnell, 2008); this topographic anomaly is attributed to the persistence of a Large Low Shear Velocity Province (LLSVP) at the Core-Mantle boundary which is postulated to have generated plumes under the African plate (Torsvik et al., 2006; Burke et al., 2008). In concert with a growing chorus of general objections to the plume hypothesis (e.g. Bailey, 1993; Westaway et al., 2003; Anderson and Natland, 2005, 2006; Foulger, 2007), we draw attention to major inconsistencies between the actual topography of southern Africa and the dynamic topography predicted by plume-based models.

\section{Observed vs. modelled topography of southern Africa}

As a first order generalization, areas of elevated topography in southern Africa are associated with the marginal escarpment, while the interior is the site of the Cenozoic Kalahari sedimentary basin (Fig. 1). The drainage network is characterized by a remarkable pattern of river divides (Fig. 2), which define three horseshoeshaped arcs, broadly concentric with the coastline (Moore, 1999). The outer arc follows the crest of the Great Escarpment, and separates relatively short coastal rivers from the main drainages of the inland plateau. The middle divide separates the Orange River basin from the Limpopo, and cuts across an abandoned former link between the Molopo-Nossib and the Orange Rivers (Moore, 1999). The innermost divide separates the major Limpopo and Zambezi drainage basins in Zimbabwe, and the Limpopo from fossil endoreic river lines in Botswana.

In contrast to the observed topography, geophysical models attempting to explain the unusually elevated topography of southern Africa in terms of a plume-sustained model, predict that this region will be characterized by a broad domal upwarp, and thus fail to explain the interior Cenozoic Kalahari sedimentary basin (Fig. 1). Predicted low ground at the southern margin of the plume-modelled dome (Lithgow-Bertelloni and Silver, 1998) is in fact the location of the highest ground on the sub-continent, in the Drakensberg-Maluti mountain-land. The model predicts relatively high ground over the bulge of the low-lying $(<200 \mathrm{~m})$ Mocambique coastal plain, while the markedly elevated ground of the Khomas Highlands in Namibia and Bié Plateau in Angola (Fig. 1) both occur on the margins of the plume-modelled dome. The plume model also implicitly requires that southern Africa should be characterized by a radial drainage pattern, and fails to predict or explain the remarkable 


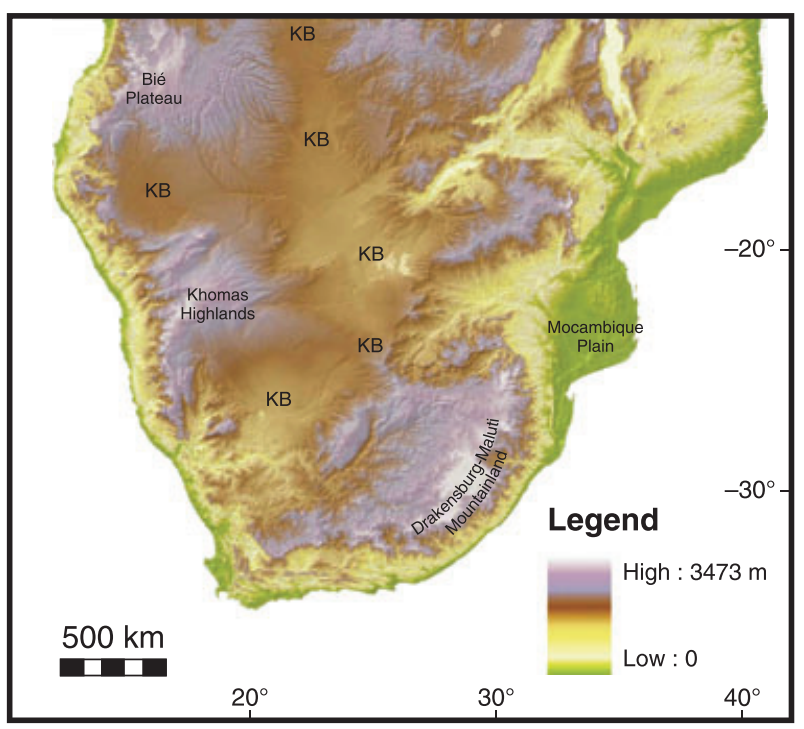

Fig. 1 SRTM digital elevation image for southern Africa. Note that the highest elevations (purple-grey tones) are associated with the marginal escarpment and also the central Zimbabwe watershed. This high ground surrounds the Cenozoic Kalahari Basin (KB). Elevations in metres.

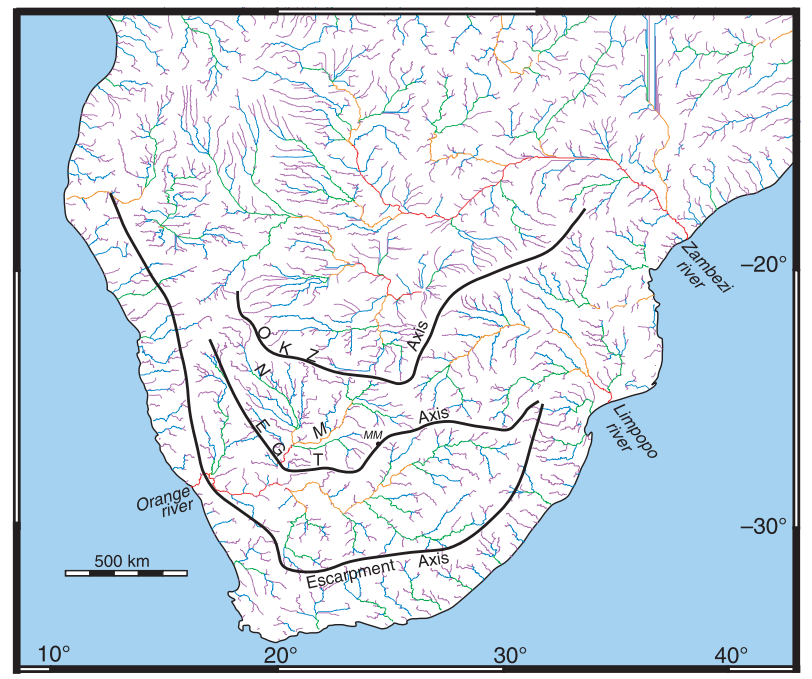

Fig. 2 Drainage system of southern Africa. Colours denote stream rank from red (1) to purple (5). M, Molopo River; N, Nossob River; MM, Mahura Muhtla. The major river divides are interpreted to reflect epeirogenic uplift Axes. EGT Axis, EtoshaGriqualand-Transvaal Axis; OKZ Axis, Ovambo-Kalahari-Zimbabwe Axes. Data from USGS EROS, http://eros.usgs.gov/products/elevation/gtopo30/hydro/af_ streams.html

observed concentric pattern of river divides in southern Africa. In short, the first-order topography of southern Africa does not correspond with the dynamic topography predicted by the plume model. Therefore the observed topography demands alternative explanations.

\section{Evolution of the topography of southern Africa}

The three major river divides all cut across geological boundaries and structural lineaments (Fig. 3), and therefore do not reflect simple lithological controls. Rather, the divides have been interpreted to reflect axes of epeirogenic flexure (Du Toit, 1933; King, 1963; Moore, 1999), designated, from the coast inland, the Escarpment Axis, the Etosha-Griqualand-Transvaal (EGT) Axis and the OvamboKalahari-Zimbabwe (OKZ) Axis. The evidence that the three major river divides represent lines of epeirogenic flexures is very compelling. The Escarpment Axis is well modelled as a line of isostatic flexure, related to the erosion of the coastal plain following breakup of Gondwana (Gilchrist and Summerfield, 1991; Moore and Blenkinsop, 2006). Relative uplift along the EGT Axis is reflected by the preservation of a dismembered relic of a fossil drainage line straddling the flexure at Mahura Muthla (Fig. 2). The abandoned link between the Molopo and Orange Rivers has a convex-up profile where it crosses this axis (Moore, 1999). This contrasts with the concave-up profile expected from headward erosion, but is consistent with uplift across the river course (Du Toit, 1933; Partridge, 1998). In the case of the OKZ Axis, there is clear evidence for reversal of drainage flow directions across this line of flexure in Botswana (Moore, 1999). In Zimbabwe, this axis was responsible for beheading an earlier drainage network established in the Permian (Moore and Moore, 2006; Moore et al., 2009). The EGT Axis forms the southern boundary of the Kalahari Formation, which crosses a variety of bedrock formations (Haddon, 1999, 2001), demonstrating that the axis is not lithologically controlled (Fig. 4). Further north, the locus of the OKZ Axis corresponds closely with the eastern and western margins of this sedimentary unit. This underlines the observation made by Du Toit (1933) that subsidence of the Kalahari Basin was closely associated with uplift along the river divides that define these two axes.

Several lines of evidence show that the flexures forming the three major river divides in southern Africa were initiated in discrete episodes (Moore, 1999). Uplift along the Escarpment Axis was initiated by the opening of the Indian and Atlantic Oceans at c. $126 \mathrm{Ma}$ (King, 1963; Moore and Blenkinsop, 2006). This is reflected by a major Early Cretaceous erosional event, particularly marked along the margins of southern Africa (Brown 


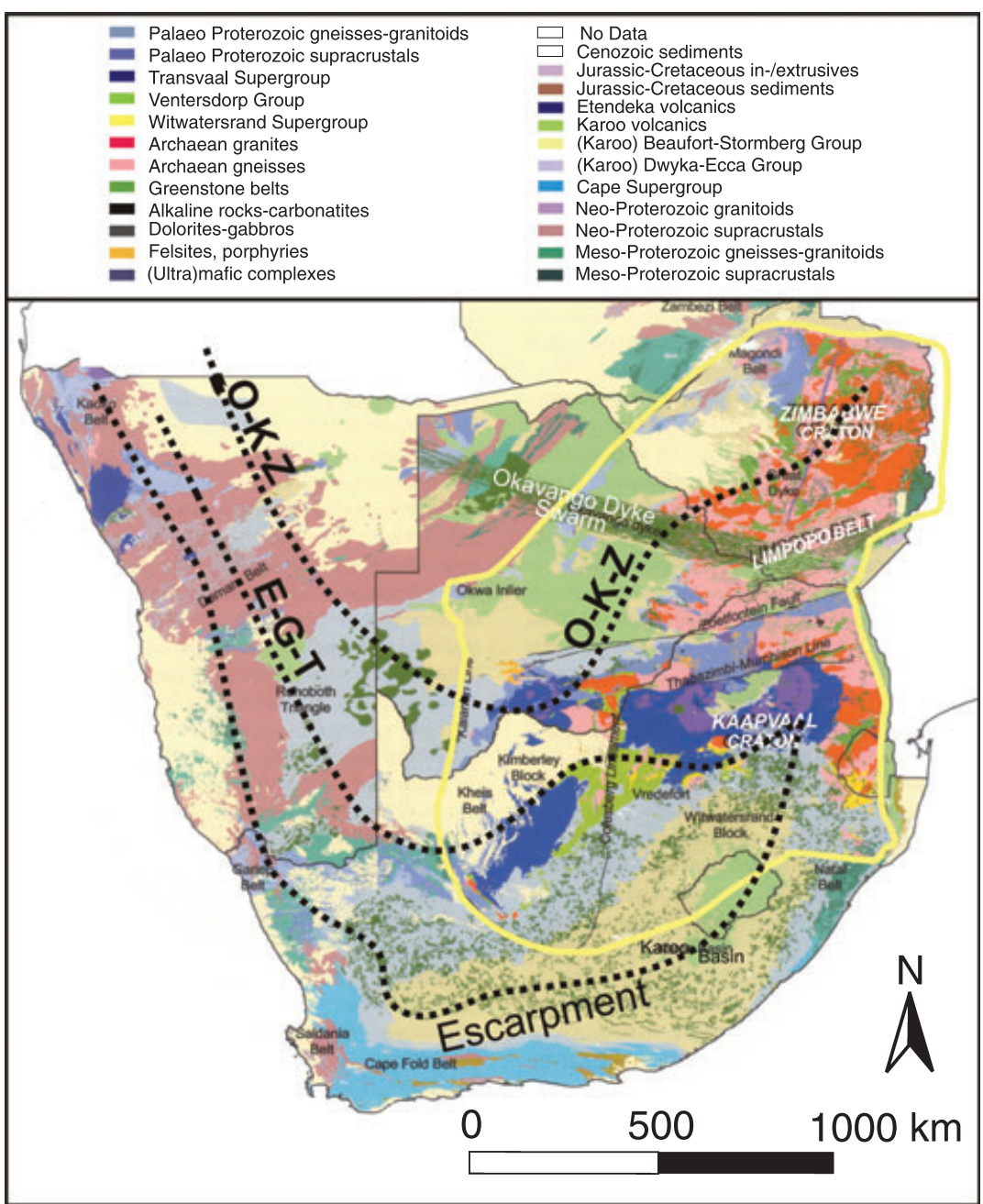

Fig. 3 Loci of major river divides, inferred to reflect axes of epeirogenic flexure, in relation to the geology of southern Africa. These divides all cross boundaries separating Archaean cratons from the surrounding Proterozoic terranes. In Namibia, they traverse the northeast-trending late Proterozoic Damara belt at a high angle. In Zimbabwe, the OKZ Axis transects the granite-greenstone terrain of the Zimbabwe craton, cuts across the NNE-trending Great Dyke, and continues across the Okavango Dyke swarm in Botswana. The central EGT Axis crosses the northtrending Kheiss belt at right angles, while much of the eastern section of the Escarpment Axis traverses readily eroded horizontal Karoo sediments. Geology of southern Africa after De Wit et al. (2004).

et al., 1990; McMillan, 2003) (Table 1 and Fig. 5). Erosion of the coastal plain resulted in the progressive inland migration of the axis as an isostatic flexure (Gilchrist and Summerfield, 1991) which continues to the present, albeit at very slow rates (Fleming et al., 1999; Brown et al., 2002).

An upper Cretaceous (85-65 Ma) age for the EGT Axis is inferred on the basis of fossil wood preserved in the Mahura Muthla palaeo-channel astride the axis (Partridge and Maud,
1987; Partridge, 1998) (Fig. 5). Recent supporting evidence for this timing comes from an Apatite Fission Track (AFT) study in Zimbabwe (Belton, 2006). Three episodes of accelerated erosion were identified in the Limpopo Valley in the south of the country (c. $125 \mathrm{Ma}$, c. $83 \mathrm{Ma}$ and 44-33 Ma) (Table 1 and Fig. 5). The first was ascribed to erosion triggered by disruption of Gondwana. Uplift along the EGT Axis, which forms the southern watershed of the Limpopo Basin, would have rejuvenated drainages with headwaters on this divide, thus initiating the mid-Cretaceous erosion event. In agreement with this interpretation, the Zambezi basin does not record accelerated denudation at this time. We propose that the youngest (late Palaeogene) erosion event was triggered by uplift along the OKZ Axis, that forms the central Zimbabwe watershed, separating the Limpopo and Zambezi Basins (Moore et al., 2009). Coeval erosion in the Zambezi basin (Belton, 2006) (Table 1) is consistent with this interpretation, which further explains the marked Oligocene increase in sediment flux identified in the deltas of the Zambezi (Walford et al., 2005) and Limpopo (Burke and Gunnell, 2008), ascribed to epeirogenic continental uplift by both studies. Thus, the ages of all three axes are constrained by independent geological and AFT evidence. In the Congo sedimentary basin, major unconformities have been recognized in the Lower Cretaceous, Late Cretaceous and mid-Tertiary (Cahen and Lepersonne, 1952; Giresse, 2005; Stankiewicz and de Wit, 2006). These correspond closely in timing with the initiation of the three flexure axes in southern Africa. These temporal correlations recall Goldfinger's dry observation: 'Once is happenstance Mr. Bond. Twice is coincidence. But the third time, it is enemy action.' (Fleming, 1959). Collectively, the evidence argues for coeval continentwide uplifts.

The timing of uplift along the three flexures (Early Cretaceous, midCretaceous and Late Palaeogene) overlap episodes of alkaline volcanism in southern Africa (Moore et al., 2008) (Fig. 5). Nevertheless, while the ages of the Axes young inland from the coast, alkaline volcanism in southern Africa shows a pattern of younging in the opposite direction, towards the coast (Moore et al., 2008).

In summary, southern Africa is characterized by a remarkable pattern of roughly concentric river divides, broadly paralleling the coastline and of different ages, younging inland from the coast. Each flexure was associated with an episode of alkaline volcanism in southern Africa. Any model which invokes mantle plumes to account for the topography of southern Africa must address both the remarkable pattern of the river 


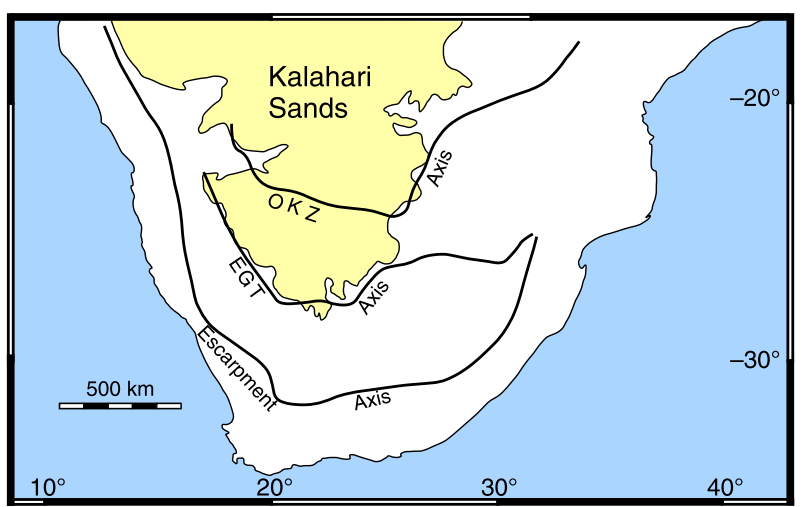

Fig. 4 Distribution of the Kalahari Formation (Kalahari Sands) in relation to the epeirogenic axes defined by the major river divides. Note how the EGT Axis encircles the southern margin of the Kalahari basin. Further to the north, the eastern and western margins of the basin are bounded by the OKZ Axis.

Table 1 Major post-Gondwana erosion episodes in southern Africa indicated by apatite fission track evidence.

\begin{tabular}{lllll}
\hline $\begin{array}{l}\text { Locality Studied } \\
\text { (from north to south) }\end{array}$ & Palaeogene & Mid-Cretaceous & Early Cretaceous & Reference \\
\hline $\begin{array}{l}\text { Zambezi Valley, Zimbabwe } \\
\text { Limpopo Valley, Zimbabwe }\end{array}$ & $47-37 \mathrm{Ma}$ & & $133-124 \mathrm{Ma}$ & Belton (2006) \\
Northwest coastal plain & & $93-73 \mathrm{Ma}$ & $128-118 \mathrm{Ma}$ & Belton (2006) \\
$\begin{array}{l}\text { Northeast coastal plain } \\
\text { Cape Fold Belt, South coast }\end{array}$ & & $130-100 \mathrm{Ma}$ & Brown et al., 1990 \\
\hline
\end{tabular}

divides, and the timing of their initiation. It must also account for the inland younging of the flexures and coastward migration of alkaline volcanism in southern Africa, since the disruption of Gondwana. As the domal uplifts predicted by the plume model fail to account for these observations, it is necessary to seek alternative explanations.

The three southern African flexure axes are not only parallel to the coastline, but also to the surrounding ocean-spreading ridges. There are close correlations between the ages of initiation of the three flexures and major episodes of plate reorganization in the Atlantic and Indian Ocean (Moore et al., 2008) (Fig. 5). Thus, initiation of the coastal Escarpment Axis in the Early Cretaceous corresponds to the inception of the drift sequence in sedimentary basins surrounding southern Africa (McMillan, 2003). Continental instability following separation of the Agulhas Bank and Falkland plateau at c. $100 \mathrm{Ma}$ may have rejuvenated erosion of the coastal plain and thus uplift along the
Escarpment Axis (Moore et al., 2008). The upper age limit (c. $85 \mathrm{Ma}$ ) for the initiation of the mid/late-Cretaceous EGT Axis closely matches the timing of a major shift in the pole of rotation of the Atlantic at Chron 34 (c. $84 \mathrm{Ma}$ ) (Nürnberg and Müller, 1991), and follows shortly after a reorganization of spreading in the Indian Ocean dated at c. $90 \mathrm{Ma}$ (Reeves and de Wit, 2000). The late Palaeogene OKZ Axis correlates closely in age with a reorganization of the Indian Ocean spreading regime (Reeves and de Wit, 2000), as well as a marked increase in spreading rate in the midAtlantic (Nürnberg and Müller, 1991) (Fig. 5).

These correlations suggest that the flexure axes, and thus topography in southern Africa, could be primarily linked to deformation events associWhile the exact mechanisms are subject matters involving speculation and accordingly require further investigation, major episodes of erosion in the British Isles have been correlated with plate boundary deformation (Hillis ated with these plate reorganizations. et al., 2008; Holford et al., 2009). The projection of compressional stresses over distances $>1000 \mathrm{~km}$ from oceanic ridges into the interiors of continental plates 'can account for a broad spectrum of shortening-related intraplate deformation styles which vary in scale from upper crustal folding ... to whole lithosphere buckling' (Holford et al., 2009).

The disparity between the actual topography of southern Africa and plume-based numeric models does not necessarily rule out the existence of the putative African Superplume. Nevertheless, the evidence presented in this article demonstrates that the modern topography of southern Africa reflects a complex interplay of processes, linked to plate motions, that have operated over a long period of time as compared with the short time-scales suggested for plume-sustained topography. Numerical models, which attempt to account fully for Africa's anomalously elevated topography, should not consider the possible influence of a single extant deep-mantle plume in isolation from these long-term processes.

\section{Implications for continent-wide erosion cycles and the origin of uplifts}

Our observations have an important bearing on one of the most celebrated debates in geomorphology - the concept of cyclic erosion episodes. This was championed by Lester King (1949, 1955, 1963), who recognized relics of successive erosion surfaces of different ages in southern Africa, including the senile African Surface, with a continent-wide distribution.

A major criticism of the concept of cyclic erosion surfaces has always been the question of the mechanisms responsible for their initiation. This problem is resolved by successive uplift along axes located progressively inland from the coast. Each episode of epeirogenic tectonism would have rejuvenated the drainage network of southern Africa, thus providing a series of triggers to initiate new cycles of erosion in the continental interior. This in turn offers a theoretical framework to account for the succession of erosion cycles previously recognized in southern Africa (King, 1963; Lister, 1987; Partridge and Maud, 1987). 


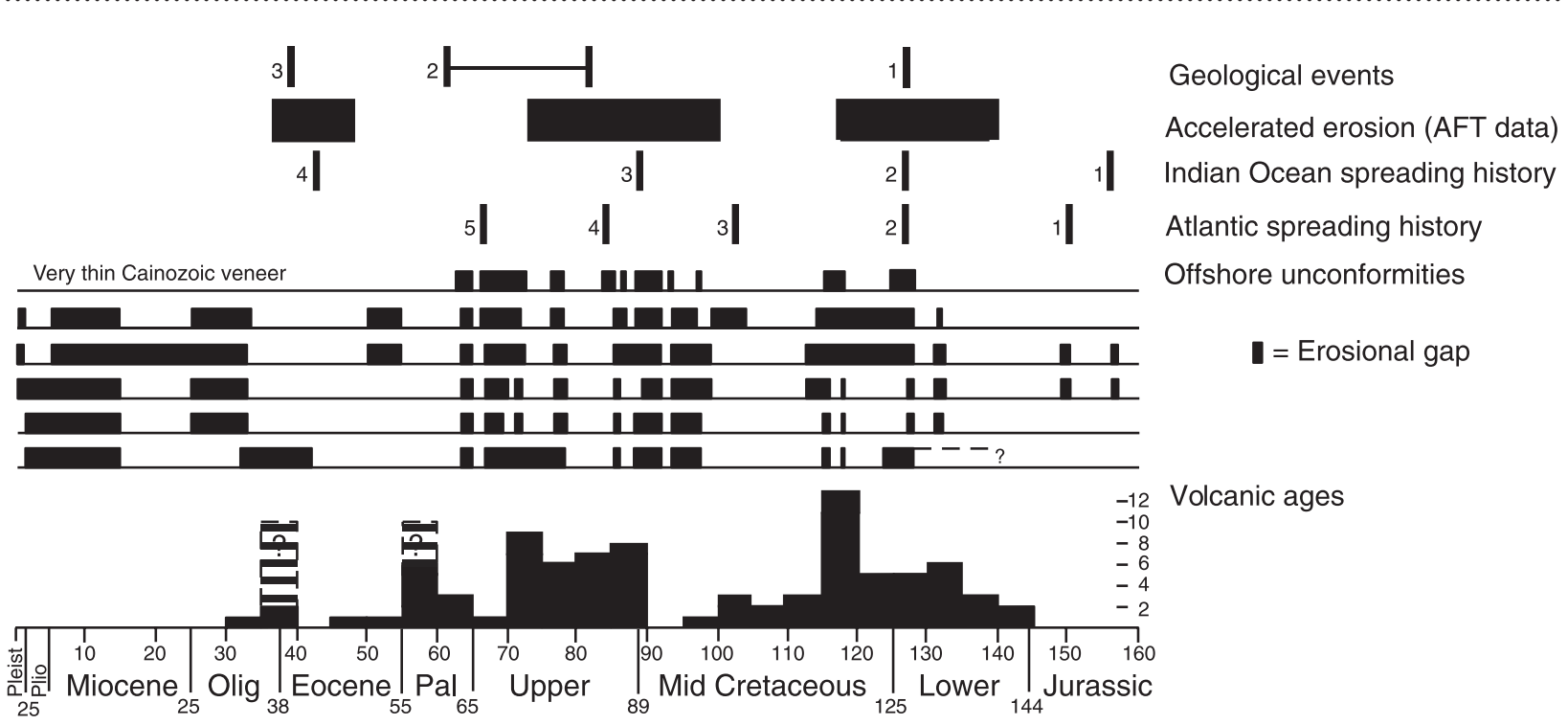

Fig. 5 Comparison of the geological events that constrain the ages of uplift axes, Indian and Atlantic Ocean opening histories, offshore basin erosion histories and ages of alkaline volcanic rocks (based on Moore et al., 2008). Geologic events are: (1) Start of Atlantic opening (McMillan, 2003) and initiation of Escarpment Axis; (2) Maximum/minimum age bracket for disruption of Mahura Muthla palaeo-drainage (Partridge, 1998) reflecting EGT Axis uplift; (3) Increased sedimentation in the major Zambezi and Limpopo River deltas (Walford et al., 2005; Burke and Gunnell, 2008) ascribed to uplift along the OKZ Axis. Offshore unconformities data are from McMillan (2003) within the Kwa Zulu, Algoa, Gamtoos, Pietmos, Bredasdorp, and Orange basins respectively (from top to bottom). Indian Spreading History from McMillan (2003) and Reeves and de Wit (2000): (1) Initial rifting between Africa and Antarctica; (2) Commencement of spreading; (3) and (4) Changes in Indian Spreading regime recognized by Reeves and de Wit (2000). Atlantic Spreading History (from Nürnberg and Müller, 1991; Dingle and Scrutton, 1974): (1) Rifting extends into southern Atlantic Ocean; (2) Commencement of opening of Atlantic (drift sequence); (3) Estimated time of separation of Falkland Plateau and Agulhas bank, based on assumed spreading rates; (4) Major shift in pole of rotation of African/South American plates; (5) Beginning of progressive shift in pole of rotation of African/South American plates. Sources of volcanic ages are quoted in Table 1 of Moore et al. (2008). Dashed lines and question marks are for the Chameis Bay pipes, denoting the two different ages indicated by field relationships and very limited radiometric dating.

Close correlation between the ages of these flexure axes and the major unconformities in the Congo Basin lends support for the development of contemporaneous erosion surfaces over wide areas of Africa, as postulated by King (1963). A re-evaluation of erosion surfaces in southern African in relation to the three flexure axes offers a potential framework for refining understanding of their chronology and interrelationships.

It has been noted that the ages of the three flexure axes also correspond to continent-wide episodes of alkaline volcanism recognized by Bailey (1993), underlining the link between epeirogenesis and associated lithospheric stresses, and alkaline volcanism (Bailey, 1993; Moore et al., 2008). The broad upwarps represented by the flexure axes would be associated with relative tensional stresses in the upper surface of the plate. In contrast, the lower plate surface would experience relative tension beneath the basins surrounding the axes. This link between the uplift axes and the distribution of sub-lithospheric stresses could explain the coastward younging of alkaline volcanism in southern Africa, which contrasts with the inland age progression of the three axes.

In addition to the flexures represented by the major drainage divides in southern Africa, a number of lines of Plio-Pleistocene uplift have affected topography to a lesser extent (Du Toit, 1933; Partridge, 1998; Moore, 1999), but a discussion of their origin is beyond the scope of this paper.

In summary, the observed topography of Southern Africa does not correlate well with dynamic topography predicted by plume models. Rather, topography is largely determined by concentric flexural uplift axes, each coeval with an episode of plateboundary reorganization. This suggests that the dominant influence on the modern topography in southern Africa reflects stresses associated with plate kinetics, rather than mantle plumes.

\section{Acknowledgements}

Tyrel Flugel is thanked for producing the Digital Elevation image of southern Africa, and Dr Marty McFarlane, Paul Green and two anonymous reviewers for their constructive comments on the manuscript.

\section{References}

Anderson, D.L. and Natland, J.H., 2005. A brief history of the plume hypothesis and its competitors: concept and controversy. Geol. Soc. Amer. Spec. Paper, 238 , 119-145.

Anderson, D.L. and Natland, J.H., 2006. Evidence for mantle plumes? Nature, 450, E15.

Bailey, D.K., 1993. Petrogenic implications of the timing of alkaline, carbonatite and kimberlite igneous activity in Africa. $S$. Afr. J. Geol., 96, 67-74.

Belton, D.X., 2006. The low temperature chronology of cratonic terrains, 
Unpublished PhD Thesis. University of Melbourne, Australia, 306 pp.

Bond, G., 1979. Evidence for some uplifts of large magnitude in continental platforms. Tectonophysics, 61, 28-305.

Brown, R.W., Rust, D.J., Summerfield, M.A., Gleadow, A.J.W. and de Wit, M.C.J., 1990. An accelerated phase of denudation in the south-western margin of Africa: evidence from apatite fission track analysis and the offshore sedimentary record. Nucl. Tracks. Rad. Measur., 17, 339-350.

Brown, R.W., Summerfield, M.A. and Gleadow, A.J.W., 2002. Denudational history along a transect across the Drakensberg Escarpment of southern Africa derived from apatite fission track thermochronology. J. Geoph. Res., 107(B12), 2350, doi:10.1029 2001JB000745.

Burke, K., 1996. The African Plate. S. Afr. J. Geol., 99, 339-409.

Burke, K. and Gunnell, Y., 2008. The African Erosion Surface: a continentalscale synthesis of geomorphology, tectonics, and environmental change over the past 180 million years. Geol. Soc. Amer. Mem., 201, 1-66.

Burke, K., Steinberger, B., Torsvik, T.T. and Smethurst, M.A., 2008. Plume Generation Zones at the margins of Large Low Shear Velocity Provinces on the core-mantle boundary. Earth Planet. Sci. Lett., 286, 49-60.

Cahen, L. and Lepersonne, J., 1952. Équivalence entre le Système du Kalahari du Congo belge et les Kalahari beds d'Afrique australe. Mém. Belge Géol. Pal. Hydrol. Soc.. 4, 63pp.

De Wit, M.J., Richardson, S.H. and Ashwal, L.D., 2004. Kaapvaal Craton special volume - an introduction. S. Afr. J. Geol., 2004, 1-6.

Dingle, R.V., Scrutton, R.A. (1974). Continental break-up and the development of post-Palaeozoic sedimentary basins around southern Africa. Bull. Geol. Soc. Am. 85, 1467-1374.

Du Toit, A.L., 1933. Crustal movements as a factor in the geographical evolution of South Africa. S. Afr. Geograph. J., 16, $1-33$.

Ebinger, C.J. and Sleep, N.H., 1998. Cenozoic magmatism throughout east Africa resulting from impact of a single plume. Nature, 395, 788-791.

Fleming, I. (1959). Goldfinger. Cape, London, 318pp.

Fleming, A., Summerfield, M.A., Stone, J.O., Fifield,L.K. and Cresswell, R.G., 1999. Denudation ratesfor thesouthern Drakensbergescarpment,SEAfrica, derived from in-situ produced cosmogenic ${ }^{36} \mathrm{Cl}$ :initialresults.J.Geol.Soc.London, 156, 209-212.
Foulger, G., 2007. The "plate" model for the genesis of melting anomalies. Geol. Soc. Amer. Spec. Paper, 430, 1-28.

Gilchrist, A.R. and Summerfield, M.A., 1991. Denudation, isostacy and landscape evolution. Earth Surf. Proc. Land., 16, 555-562.

Giresse, P., 2005. Mesozoic-Cenozoic history of the Congo Basin. J. Afr. Earth Sci., 43, 301-315.

Gurnis, M., Mitrovica, J.X., Ritsema, J. and van Heijst, H-J., 2000. Constraining mantle density structure using geological evidence of surface uplift rates: the case of the African superplume. Geochem. Geophys. Geosystems, 1, 1-44.

Haddon, I.G., 1999. Isopach Map of the Kalahari Group, 1:2 500 000. Council for Geoscience, South Africa.

Haddon, I.G., 2001. Sub-Kalahari Geological Map, 1:2 500 000. Council for Geoscience, South Africa.

Hillis, R.R., Holford, S.P., Green, P.F., Dorž, A.G., Gatliff, R.W., Stoker, M.S., Thomson, K., Turner, J.P., Underhill, J.R. and Williams, G.A., 2008. Cenozoic exhumation of the southern British Isles. Geology, 36, 371-374.

Holford, S.P., Green, P.F., Duddy, I.R., Turner, J.P., Hillis, R.J. and Stoker, M.S., 2009. Regional intraplate exhumation episodes related to plate boundary deformations. Geol. Soc. Amer. Bull. (in press).

King, L.C., 1949. On the ages of African land-surfaces. Q. J. Geol. Soc., 104, 439-459.

King, L.C., 1955. Pediplanation and isostasy: an example from South Africa. Q. J. Geol. Soc., 111, 535-539.

King, L.A., 1963. The South African Scenery. Oliver and Boyd, London, 308pp.

Lister, L.A. 1987. The erosion surfaces of Zimbabwe. Bull. Zim. Geol. Survey 90, 163pp.

Lithgow-Bertelloni, C. and Silver, P., 1998. Dynamic topography, plate driving forces and the African superswell. Nature, 395, 269-272.

McMillan, I.K., 2003. Foraminiferally defined biostratigraphic episodes and sedimentary patterns of the Cretaceous drift succession (Early Barremian to Late Maastrichtian in seven basins on the South African and southern Namibian continental margin. S. Afr. J. Sci., 99, 537-576.

Moore, A.E., 1999. A reappraisal of epeirogenic flexure axes in southern Africa. S. Afr. J. Geol., 102, 363-376.

Moore, A.E. and Blenkinsop, T.G., 2006. Scarp retreat versus pinned drainage divide in the formation of the Drakensberg escarpment, southern Africa. S. Afr. J. Geol., 109, 455-456.
Moore, A.E. and Moore, J.M., 2006. A glacial ancestry for the Somabula diamond-bearing alluvial deposit, central Zimbabwe. S. Afr. J. Geol., 109, 471482.

Moore, A.E., Blenkinsop, T.G. and Cotterill, F.P.D, 2008. Controls of postGondwana alkaline volcanism in southern Africa. Earth Planet. Sci. Lett., 268, 151-164.

Moore, A.E., Cotterill, F.P.D, Broderick, T.G. and Plowes, D., 2009. Landscape evolution in Zimbabwe from the Permian to present, with implications for kimberlite prospecting. S. Afr. J. Geol., 112, 65-86.

Nürnberg, D. and Müller, R.D., 1991. The tectonic evolution of the south Atlantic from Late Jurassic to present. Tectonophysics, 191, 27-53.

Nyblade, A.A. and Robinson, S.W., 1994 The African superswell. Geophys. Res. Lett., 21, 765-768.

Partridge, T.C., 1998. Of diamonds, dinosaurs and diastrophism: 150 million years of landscape evolution in southern Africa. S. Afr. J. Geol., 101, 165-184.

Partridge, T.C and Maud, R.R., 1987. Geomorphic evolution of southern Africa since the Mesozoic. S. Afr. J. Geol., 90, 165-184.

Reeves, C. and de Wit, M.J., 2000. Making ends meet in Gondwana: retracing the transforms of the Indian Ocean and reconnecting the continental shear zones. Terra Nova, 12, 272-280.

Stankiewicz, J. and de Wit, M.J., 2006. A proposed drainage evolution model for Central Africa - Did the Congo flow east? J. Afr. Earth Sci., 44, 75-84.

Tinker, J., de Wit, M. and Brown, R., 2008. Mesozoic exhumation of the southern Cape, South Africa, quantified using apatite fission tract thermochronology. Tectonophysics, 455, 77-93.

Torsvik, T.H., Smethurst, M.A., Burke, K. and Steinberger, B., 2006. Large igneous provinces generated from the margins of the large low-velocity provinces in the deep mantle. Geophys. J. Int., 167, $1447-1460$

Walford, H.L., White, N.J. and Sydow, J.C., 2005. Solid sediment load history of the Zambezi Delta. Earth Planet. Sci. Lett., 238, 49-63.

Westaway, R., Bridgland, D. and S. Mishra, S., 2003. Rheological differences between Archaean and younger crust can determine rates of Quaternary vertical motions revealed by fluvial geomorphology. Terra Nova, 15, 287-298.

Received 5 January 2009; revised version accepted 18 May 2009 